\title{
MS: en hoe verder?
}

Citation for published version (APA):

Hupperts, R. (2009). MS: en hoe verder? Maastricht University. https://doi.org/10.26481/spe.20090424rh

Document status and date:

Published: 24/04/2009

DOI:

10.26481/spe.20090424rh

Document Version:

Publisher's PDF, also known as Version of record

\section{Please check the document version of this publication:}

- A submitted manuscript is the version of the article upon submission and before peer-review. There can be important differences between the submitted version and the official published version of record.

People interested in the research are advised to contact the author for the final version of the publication, or visit the DOI to the publisher's website.

- The final author version and the galley proof are versions of the publication after peer review.

- The final published version features the final layout of the paper including the volume, issue and page numbers.

Link to publication

\footnotetext{
General rights rights.

- You may freely distribute the URL identifying the publication in the public portal. please follow below link for the End User Agreement:

www.umlib.nl/taverne-license

Take down policy

If you believe that this document breaches copyright please contact us at:

repository@maastrichtuniversity.nl

providing details and we will investigate your claim.
}

Copyright and moral rights for the publications made accessible in the public portal are retained by the authors and/or other copyright owners and it is a condition of accessing publications that users recognise and abide by the legal requirements associated with these

- Users may download and print one copy of any publication from the public portal for the purpose of private study or research.

- You may not further distribute the material or use it for any profit-making activity or commercial gain

If the publication is distributed under the terms of Article $25 \mathrm{fa}$ of the Dutch Copyright Act, indicated by the "Taverne" license above, 


\section{Maastricht University}

Raymond Hupperts

Faculty of Health, Medicine and Life Sciences

MS: en hoe verder?

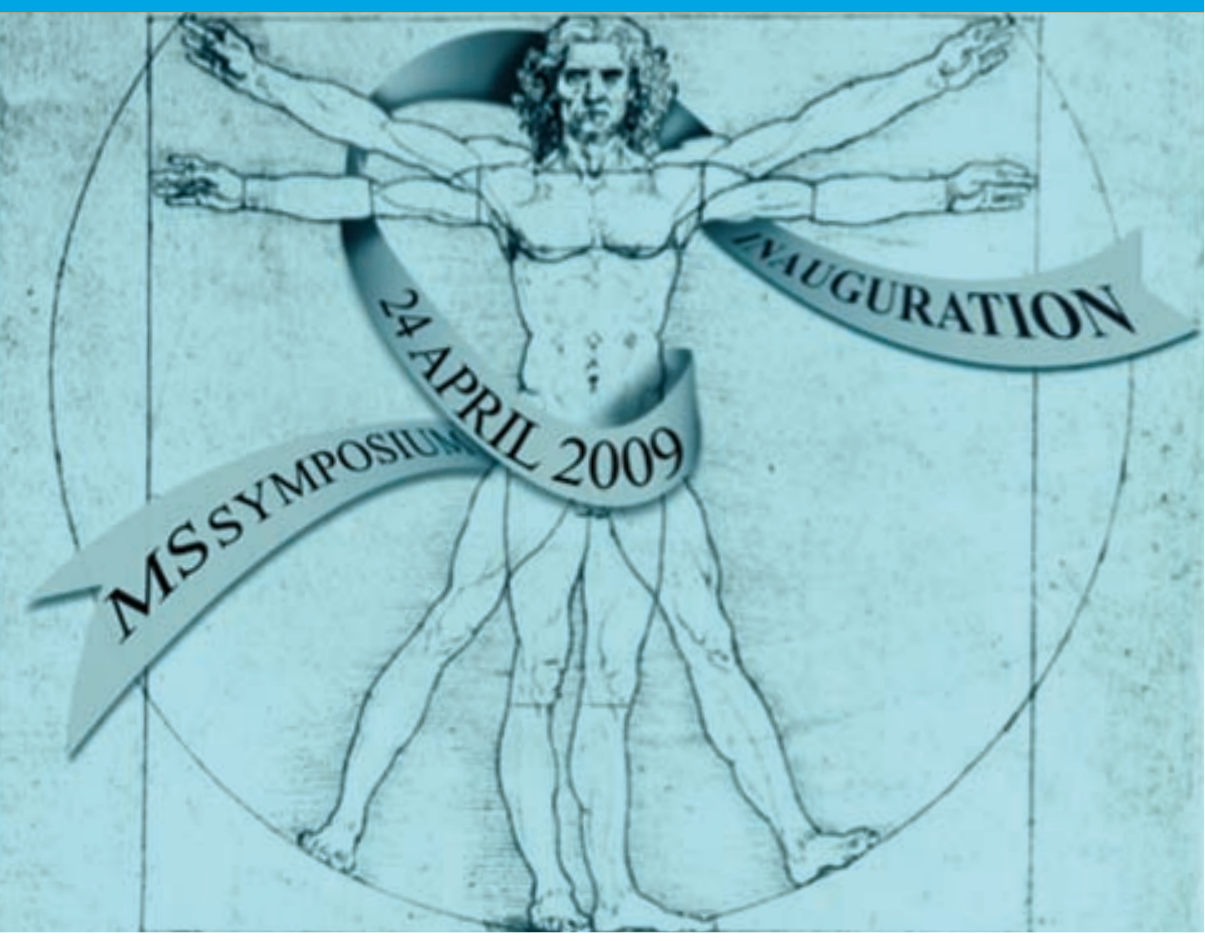


MS: en hoe verder? 


\section{Colofon}

Design and print: Océ Business Services, Maastricht

ISBN: $\quad 9789056813116$

NUR: 870

Alle rechten voorbehouden. Niets uit deze uitgave mag worden verveelvoudigd, opgeslagen in een geautomatiseerd gegevensbestand of openbaar gemaakt worden, zonder voorafgaande schriftelijke toestemming van de auteur of uitgever. 


\section{MS: en hoe verder?}

In verkorte vorm uitgesproken bij de aanvaarding van het ambt hoogleraar aan de Faculty of Health, Medicine and Life Sciences van de Universiteit Maastricht.

Op 24 april 2009

Door Raymond Hupperts 
MS: en hoe verder? 
Meneer de rector magnificus, geacht college van bestuur van de Faculty of Health, Medicine and Life Sciences, geachte decaan, geachte raad van bestuur van het Maastricht Universitair Medisch Centrum, geachte raad van bestuur van het Orbis Medisch Centrum, beste vrienden, familie, collega's en verdere toehoorders.

Voor mij is het een grote eer vandaag, nu ik het ambt van hoogleraar officieel aanvaard, deze inaugurele rede voor $u$ allen te mogen uitspreken.

To my foreign guests I apologize for the fact that this oration has to be delivered in Dutch.

De hoogleraarspositie die mij is aangeboden, omvat niet alleen de zorg voor MS-patiënten in het Academisch MS Centrum Limburg, dat centraal is gelegen in het prachtige Orbis Medisch Centrum te Geleen/Sittard, maar ook onderzoek aan de Faculty of Health, Medicine and Life Sciences hier verder FHML genoemd, het Maastricht Universitair Medisch Centrum Plus, hier verder MUMC genoemd en patiëntgebonden onderzoek in het Orbis Medisch Centrum. Deze unieke constructie maakt deze opdracht voor mij tot een fantastische uitdaging, een voorrecht.

De hierna volgende onderwerpen wil ik graag met u bespreken:

- achtergronden van de ziekte MS

- behandeling

- toekomstige ontwikkelingen

- het regionaal academisch MS-centrum

- wetenschappelijk onderzoek 


\section{Wat is MS?}

Multiple sclerose, hier verder MS genoemd, is een chronische ziekte van het centrale zenuwstelsel, te weten de hersenen en het ruggenmerg. In Nederland hebben 1 op de 1.000 mensen MS en zijn er dus zo'n 16.000 MS-patiënten. MS is de meest voorkomende neurologische ziekte bij jongvolwassenen. Per jaar komen er in Nederland zo'n 400 tot 500 MS-patiënten bij. Wereldwijd zijn er meer dan één miljoen MS-patiënten. De kosten voor de maatschappij zijn aanzienlijk: een MS-patiënt kost de overheid 9.000 tot 78.000 euro per jaar aan zorg en behandeling, afhankelijk van de ernst van de ziekte?.

De ziekte openbaart zich meestal bij jongvolwassenen, zo tussen het twintigste en dertigste levensjaar en in twee derde deel van de gevallen betreft het vrouwen. MS komt ook voor bij kinderen en dan vooral bij meisjes. De ziekteduur is gemiddeld dertig tot vijfendertig jaar, variërend van vijftien tot vijfenveertig jaar. De ziekte kan mild verlopen, maar verloopt toch vaak dramatisch. Uiteindelijk overlijden MS-patiënten niet aan de ziekte zelf maar aan complicaties van de ziekte zoals longontsteking of ernstige urineweginfecties.

Door het binnendringen van witte bloedcellen raakt bij MS de isolatielaag, het myeline van de zenuwbanen, de axonen genaamd, stukje bij beetje beschadigd. Vroeg of laat raken ook de zenuwbanen zelf beschadigd. Door deze beschadiging van de isolatielaag en de zenuwbanen kunnen de spieren niet meer worden aangestuurd en wordt onder meer de gevoelswaarneming gestoord. Hoewel dus bij MS de spierfunctie meestal wordt aangetast is de oorzaak ervan een zenuwbeschadiging en geen spierbeschadiging. Afhankelijk van de aard en mate van de beschadiging zijn deze verschijnselen tijdelijk of blijvend.

De klachten en verschijnselen bij MS zijn zeer uiteenlopend. In de regel begint de ziekte met neurologische uitvalsverschijnselen, meestal gevoelsstoornissen, minder vaak spierzwakte of verlamming van een been of halfzijdig. Deze verschijnselen worden vaak vooraf gegaan door blindheid van één oog ten gevolge van een beschadigde oogzenuw. Zeer veelvoorkomende klachten zijn verder chronische vermoeidheid, intellectuele functiestoornissen ofwel cognitieve stoornissen, blaas- en darmproblematiek, krampen en spasticiteit van de ledematen. 
Kenmerkend voor de eerste jaren van de ziekte is het vaak wisselende beloop: verschijnselen treden op en verdwijnen ook weer. Zo'n periode van (nieuwe) verschijnselen noemen we een exacerbatie of een relapse en deze treedt ongeveer anderhalf tot tweemaal per jaar op. Zonder behandeling leiden deze exacerbaties in de loop der jaren steeds vaker tot restverschijnselen die de patiënt uiteindelijk fors kunnen beperken. In $20 \%$ van de gevallen is de ziekte van het begin af aan progressief, de zogenoemde primair progressieve MS, maar in $65 \%$ van de gevallen treden eerst jaren lang exacerbaties op, de zogenoemde relapsing remitting MS en pas veel later progressie met of zonder exacerbaties.

\section{Diagnose}

Hoewel de diagnose MS een klinische diagnose is, wat wil zeggen dat deze gesteld kan worden op grond van de klachten, de verschijnselen en het ziektebeloop, zijn deze ziektetekenen niet specifiek voor de ziekte. Daarom is extra hulponderzoek nodig om de diagnose zeker te stellen, maar helaas is er hiervoor geen eenvoudige test of bloedonderzoek die de diagnose bewijst. De ontwikkelingen op het terrein van MRI-scanning en de recent ontwikkelde nieuwe diagnostische (MRI-)criteria volgens McDonald hebben er echter toe bijgedragen dat de diagnose MS steeds

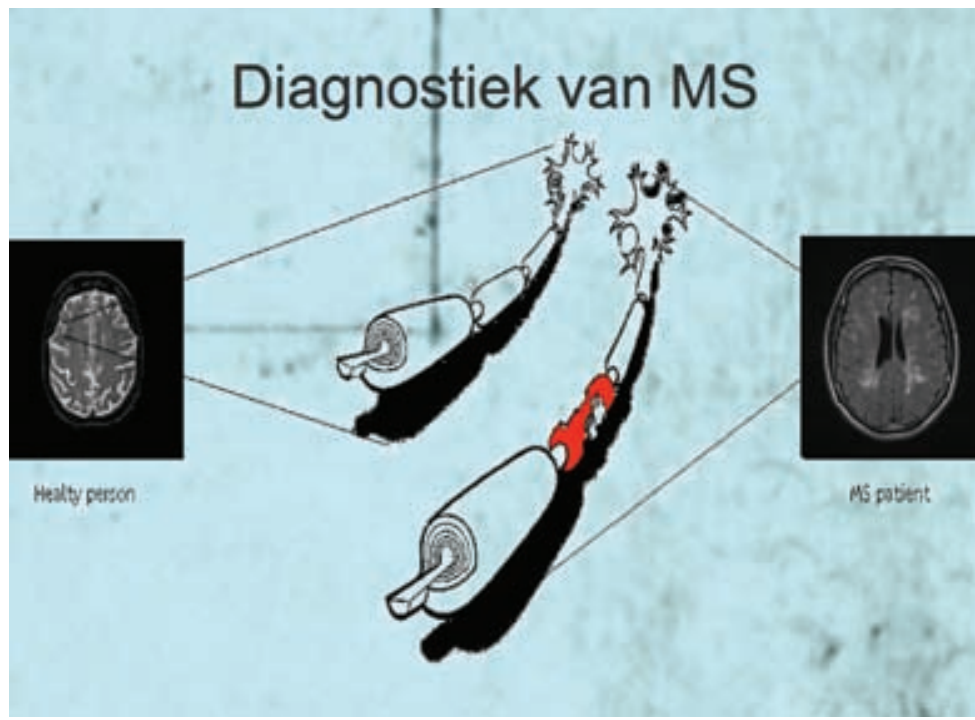


vroeger en met meer zekerheid gesteld kan worden ${ }^{2}$ Dit is van groot belang voor de eventueel in te stellen behandeling zoals zodadelijk duidelijk zal worden.

De MRI toont kleine, vaak in elkaar overgaande letsels bij ongeveer $95 \%$ van de MS-patiënten. De plaatsen waar deze letsels voorkomen en hun verschijningsvorm hebben kenmerken die typisch zijn voor MS, maar toch zijn ze soms moeilijk te onderscheiden van wittestofletsels door andere ziekten. Dit is zeker het geval bij personen ouder dan vijftig jaar.

Het stellen van de diagnose MS is vaak lastig en heeft grote consequenties voor de patiënt. Om MS van andere ziekten te onderscheiden, is het soms nodig het hersenvocht te onderzoeken door middel van een ruggenprik. Dit vocht kan voor MS typische ontstekingseiwitten tonen, of andere afwijkingen die juist niet op MS wijzen. Bij $80 \%$ van de patiënten begint de ziekte met een periode van neurologische verschijnselen die zich beperken tot één lichaamsdeel. Dit is het zogenoemde Clinical Isolated syndrome (CIS). Als deze verschijnselen gepaard gaan met voor MS kenmerkende afwijkingen op de MRI, is de kans op het ontwikkelen van MS 50\% na twee jaar en 85\% na twintig jaar ${ }^{3}$. Dat wil zeggen dat de kans dat de patiënt MS krijgt redelijk groot is, maar dat het geen zekerheid is. Nogal eens duurt het jaren voordat de diagnose MS met zekerheid gesteld kan worden.

Om een en ander wat inzichtelijker te maken presenteer ik $u$ nu gefaseerd het ziektebeeld van een inmiddels 45 -jarige man. We gaan 10 jaar terug. De toen 35-jarige man, hoog ontwikkeld, had een leidinggevende functie bij een gerenommeerd bedrijf. Zijn eerste klachten waren stuurloosheid bij het lopen en dubbelzien. Na twee maanden verdwenen deze klachten weer geleidelijk. Maar enkele maanden later kreeg hij opnieuw last van dubbelzien en kreeg hij gevoelsstoornissen in de benen waardoor hij houterig ging lopen.

De geconsulteerde neuroloog liet een MRI-scan van de hersenen maken die afwijkingen liet zien die typisch zijn voor multiple sclerose en ook het onderzoek van het hersenvocht wees hierop. In het hiernavolgend gesprek vertelde de neuroloog aan patiënt de diagnose.

$\mathrm{Na}$ enkele maanden klachtenvrij te zijn geweest kreeg de patiënt forse balansproblemen, een gestoord looppatroon en ging hij opnieuw dubbelzien. Ook deze verschijnselen verdwenen weer na enkele weken, 
maar nu pas na behandeling. In de volgende drie jaren traden nog diverse keren perioden op met functiestoornissen die telkens nagenoeg spontaan verdwenen. De patiënt had dus de relapsing remitting vorm van MS.

\section{Oorzaak}

De oorzaak van MS is nog steeds grotendeels onopgehelderd. Dit is de belangrijkste sta-in-de weg voor een adequate therapie. Meest waarschijnlijk wordt de ziekte veroorzaakt door een combinatie van omgevingsfactoren en een erfelijke aanleg. Zo blijkt de ziekte vaker voor te komen in gebieden naar gelang deze verder van de evenaar liggen, hetgeen mogelijk ook samenhangt met het vitamine D-gehalte van MS-patiënten, en er zijn aanwijzingen dat delen van het vitamine D-receptorgen geassocieerd zijn met MS. Verder zijn bepaalde viruscontacten op jongvolwassen leeftijd waarschijnlijk een trigger voor de ziekte en is er nog een groot aantal andere factoren die het krijgen van de ziekte beïnvloeden, waarvan we nog onvoldoende kennis hebben, zoals luchtvervuiling, dieet, radioactieve stoffen en andere toxinen.

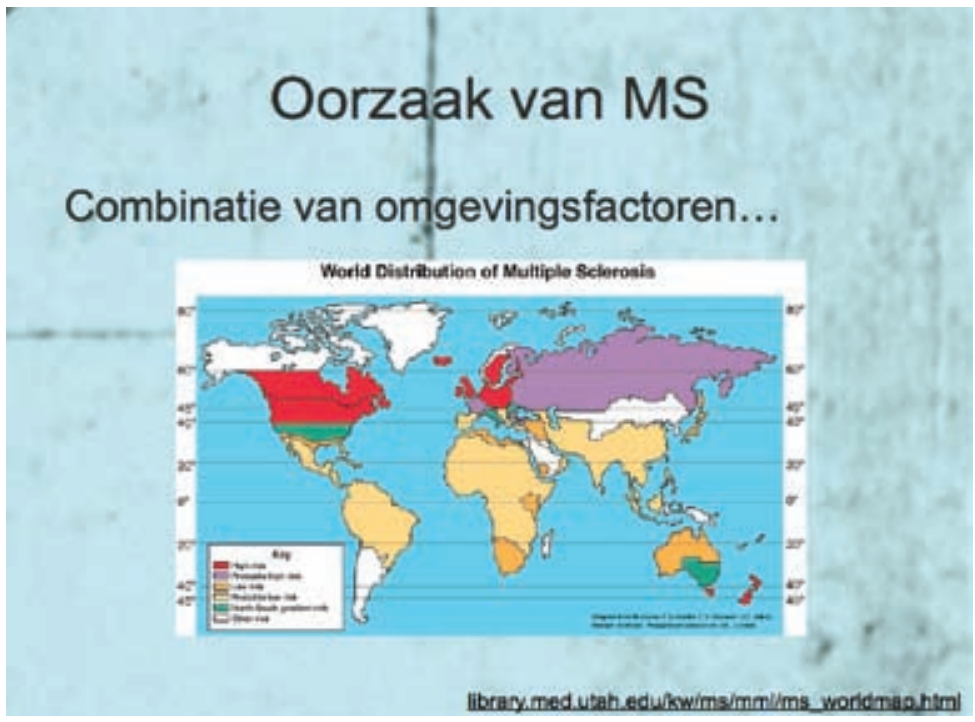




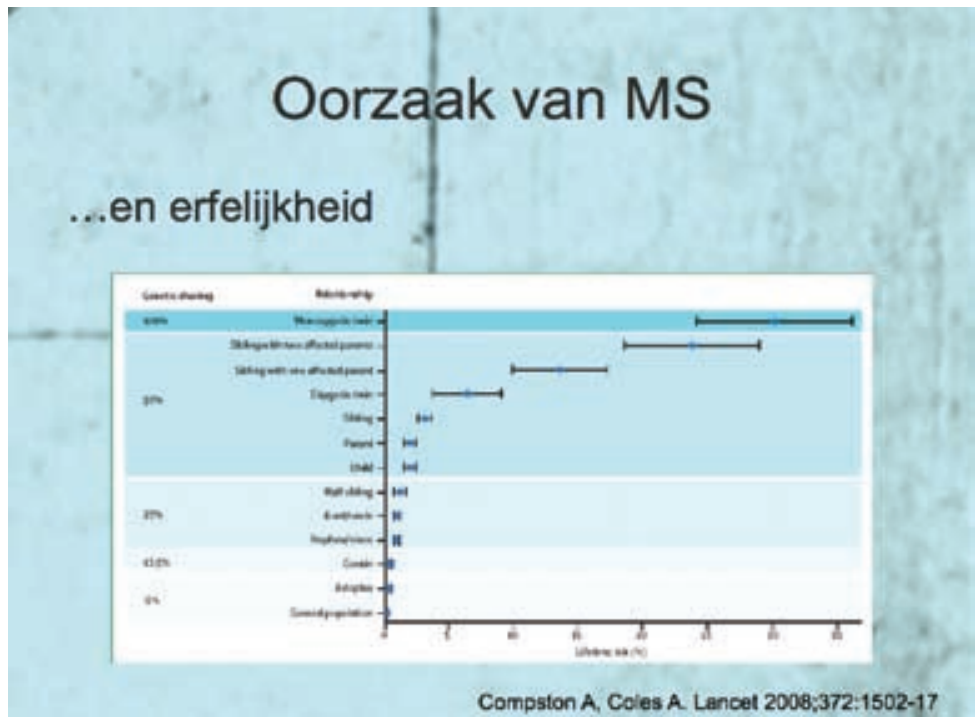

Hoewel MS geen echt genetisch overdraagbare ziekte is, speelt erfelijke belasting wel degelijk een rol bij de kans op het krijgen van de ziekte. Deze kans varieert van 2-5\% indien een familielid de ziekte heeft, terwijl dit $0.1-0.3 \%$ is in een niet erfelijk belaste populatie.

Overigens heeft zeer uitgebreid onderzoek naar genetische factoren in MS nog weinig succes opgeleverd en is nog steeds de belangwekkendste genetische bevinding de associatie van MS met het HLA DR 2-gen.

\section{Het ziektemechanisme}

Hoewel sommigen dat betwijfelen, is MS waarschijnlijk een stoornis van het afweersysteem, waarbij er een zeer complexe afweerreactie tegen eigen gezond zenuwweefsel ontstaat, een zogenoemde autoimmuunreactie. Verder zijn er diverse aanwijzingen voor verschillen in genetische activiteit tussen MS-patiënten en zijn er ten minste vier verschillende ziektemechanismen beschreven. Wellicht is MS niet één ziekte, maar een verzamelnaam voor verschillende uitingsvormen van afweerstoornissen, de zogenoemde immuunstoornissen. 
Recent onderzoek toont aan dat er weliswaar waarschijnlijk sprake is van één algemeen ontstekingsproces, T-celgemedieerde inflammatie, maar dat er vervolgens zeer diverse en complexe ontwikkelingen optreden. Dit zou kunnen verklaren waarom sommige MS-patiënten heel goed en andere juist slecht reageren op therapie.

\section{Prognose}

De prognose van MS is in de individuele patiënt buitengewoon moeilijk te stellen. Studies over het natuurlijk beloop van MS laten uiteenlopende getallen zien. De prognose per patiënt in mate en getal uitdrukken is dan ook niet zinvol. Wel zijn er factoren bekend die de prognose aanzienlijk ongunstig beïnvloeden zoals slecht herstel van een eerste exacerbatie, kort interval tot de tweede exacerbatie, een progressief begin van de ziekte en snelle toename van de wittestofafwijkingen bij MRI onderzoek ${ }^{3}$. Verder weten we nog onvoldoende wat de effecten van langdurige immunomodulerende en/of immunosupressieve behandeling zijn op de uiteindelijke prognose.

\section{Behandeling}

De eerste volledige beschrijving van het ziektebeeld multiple sclerose dateert uit 1866 en is van de hand van Jean-Martin Charcot. Het heeft sedertdien ruim honderd jaar geduurd voor de eerste behandelingen tegen multiple sclerose kwamen. Ruim een eeuw lang bestond de behandeling van MS uit leefadviezen en de bestrijding van symptomen zoals spasticiteit en pijn. Pas zo'n vijftien jaar geleden werden de eerste effectieve ziekteremmers geïntroduceerd en is de behandeling van MS in een stroomversnelling geraakt.

Deze behandeling van MS bestaat uit het voorkomen van nieuwe ziekte-uitbraken ofwel exacerbaties en het afremmen van progressie van de ziekte door middel van zogenoemde immunomodulerende of immunosuppressieve medicijnen. Deze krijgt de patiënt via injecties onder de huid, in de spier of in de aders toegediend. De medicijnen doen hun werk door verandering of onderdrukking van het immuunsysteem. Ze reduceren het aantal exacerbaties met zo'n $30 \%$ tot $40 \%$ op jaarbasis. 


\section{Behandeling van MS}

- Eerste beschrijving 1866

- Therapie tot 1993

-Rusten

-Gepaste bewegingstherapie

-Symptoombehandeling

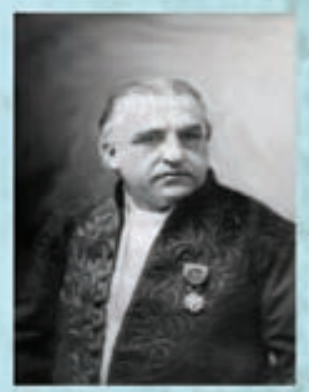

Jean-Martin Charcot (1825-1893)

Om de juiste therapie te kunnen bepalen is het van belang het beloop van de ziekte en de frequentie van de exacerbaties vast te stellen en de mate van ziekteprogressie goed in te schatten. Verder speelt de ziekteduur een rol.

Naast de symptomatische therapie heeft de multidisciplinaire begeleiding een belangrijke functie binnen de behandeling van de MS-patiënt gekregen.

Er zijn steeds meer gegevens die er op duiden dat bij MS-patiënten in een vroege fase van de ziekte, als de patiënt nog weinig ziekteverschijnselen heeft, de axonen reeds fors beschadigd kunnen zijn. Behandeling van MS spitst zich dan ook meer en meer toe op deze vroege fase. Uit diverse studies is gebleken dat het sterk te overwegen valt om bij patiënten met een eerste voor MS verdachte ziekte-uiting en MRI afwijkingen passende bij MS, het zogenoemde clinical isolated syndrome, reeds met immunomodulatie te starten ${ }^{5-9}$.

We gaan terug naar de voorbeeldcasus. Vier jaar na het ontstaan van de ziekte waren er zes exacerbaties opgetreden. $\mathrm{Na}$ een nieuwe periode van ernstige balans- en loopproblemen en zwakte van de benen werd gestart met immunomodulatie, in dit geval interferon-. Vier maanden na de start van deze behandeling kreeg patiënt echter opnieuw een zeer 


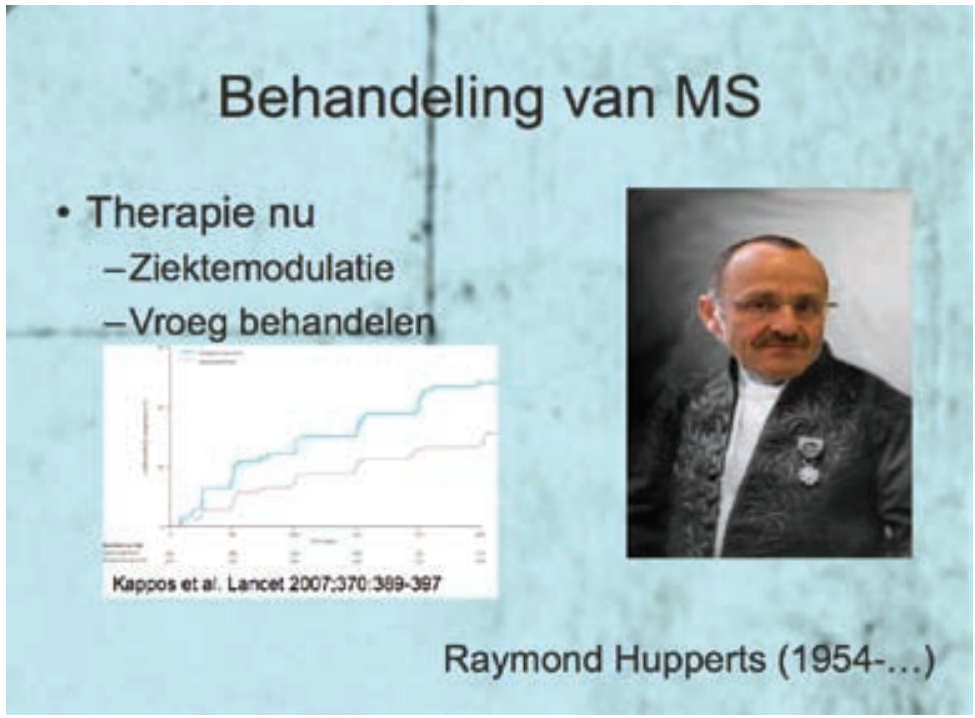

forse exacerbatie met loopstoornissen, kracht- en gevoelsstoornissen maar nu ook spraakproblemen, problemen met plassen en intellectuele functiestoornissen. Hij werd hiervoor behandeld met plasmaferese. De patiënt herstelde wonderwel maar een volgende verslechtering diende zich zes maanden later weer aan en nu was het herstel maar zeer gedeeltelijk en bleven er forse restfunctiestoornissen. Zo kon patiënt nog maar enkele tientallen meters lopen en waren er blijvende blaasfunctiestoornissen en intellectuele functiestoornissen. Inmiddels waren ook, met weinig succes, andere immunomodulerende therapieën geprobeerd. De patiënt verloor zijn baan en raakte hulpbehoevend.

In de volgende drie jaren gaat hij in fases steeds verder achteruit. Een hernieuwde MRI-scan van de hersenen toont verdere verslechtering van de uitgebreide wittestoflaesies.

$\mathrm{Na}$ opnieuw een exacerbatie krijgt patiënt het nieuwe medicijn natalizumab toegediend. Dat levert een stabilisatie op, ja zelfs zeer geringe verbetering van zijn neurologische toestand. De patiënt kan zich met een rollator redelijk verplaatsen en functioneert en woont weer zelfstandig. Hij doet zelfs vrijwilligerswerk.

Wat deze casus illustreert, is dat de ziekte multiple sclerose een grillig en onvoorspelbaar beloop heeft en dat therapie beperkt succes heeft. MS is vooralsnog niet optimaal te behandelen. Het is vaak een kwestie 


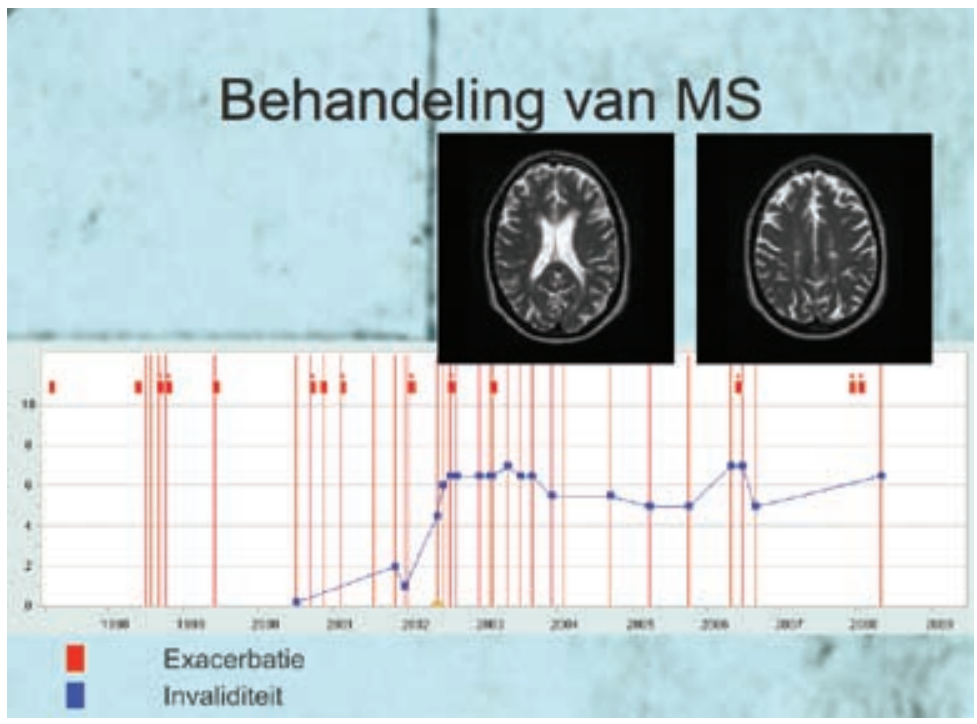

van "trial and error": werkt het ene middel niet dan mogelijk het andere. In de toekomst dient de behandeling van MS echter zo individueel mogelijk te worden ingesteld.

Zo ook de titel van het symposium van vandaag:

individually tailored therapy!

Gezien de soms grote verschillen in ziekte-uitingsvorm, het zogenoemde fenotype, en de verschillen in afweerreactie, de immuunrespons, is het niet verwonderlijk dat sommige patiënten uitstekend en anderen juist in het geheel niet op een bepaald medicament reageren.

Succesvollere therapie is derhalve een kwestie van maatwerk al zal de exactheid waarmee Leonardo da Vinci dit in zijn Man van Vitruvius tot uiting liet komen wel wat erg hoog gegrepen zijn.

Op welke wijze kunnen wij nu dit maatwerk bereiken of benaderen?

De eerste manier is het verder ontwikkelen van de kennis van het erfelijk materiaal, dat niet alleen geassocieerd is met de kans op het krijgen van MS, maar dat mogelijk ook informatie geeft over het type beloopsvorm. Eind jaren zeventig werd al het eerste gen (MHC DR15, MHC DO G) gevonden dat geassocieerd is met MS. Wie dit gen draagt, heeft een drie- tot viermaal verhoogd risico op het krijgen van MS. Maar ook 


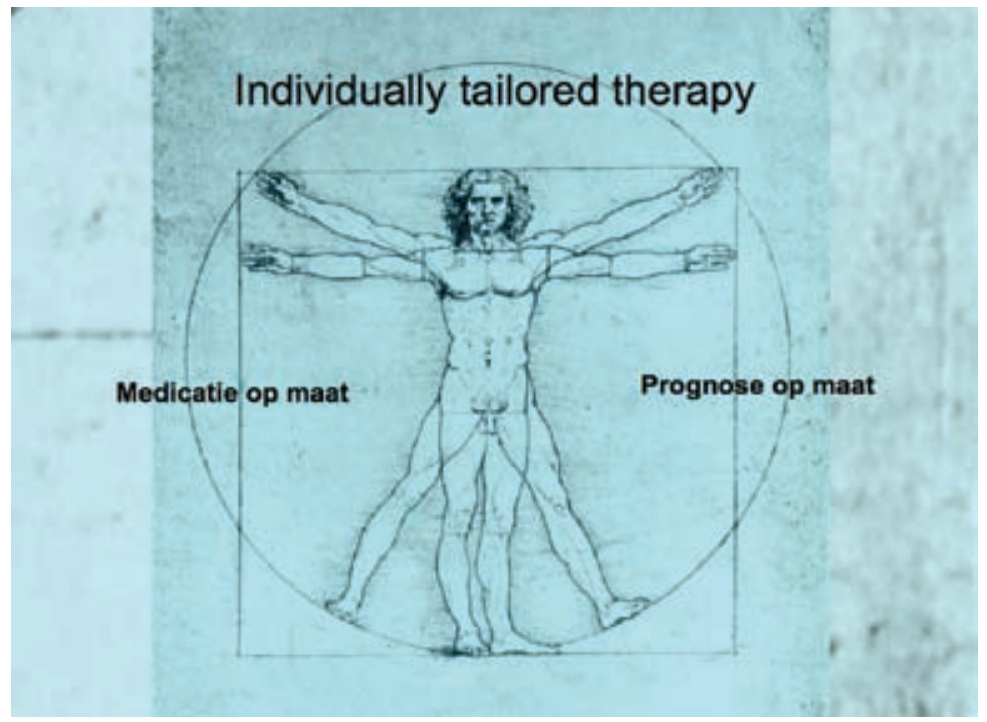

mensen die dit gen niet dragen, kunnen de ziekte krijgen. Dat suggereert dat ook andere genen een rol spelen bij MS. Van een aantal genen, te weten de interleukine 2- en 7-receptoralfa keten, is recent vastgesteld dat ze de kans op het krijgen van MS vergroten.

Bij het vergelijken van erfelijk materiaal van mensen met MS en gezonde controlepersonen wordt er ook onderzoek gedaan naar het meten van verstoorde genetische activiteit met een zeer moderne techniek: de zogenoemde DNA-micro array: dat is een chip met alle genetische informatie van de mens. Deze techniek geeft informatie over de mate van verstoring van bepaalde genen bij MS.

Het type genetische verstoring, polymorfisme of mutatie, geeft mogelijk informatie over de beloopsvorm van MS, maar ook mogelijk over andere oorzakelijke factoren van MS, bijvoorbeeld een vitamine D-gebrek of over de te verwachten effectiviteit van de behandeling.

Een verdere mogelijkheid om tot maatwerk te komen kan het proteomicsonderzoek leveren. Het betreft hier de karakterisering van eiwitten oftewel proteïnen en hun modificaties door middel van massaspectrometrie, een hoogontwikkelde techniek die het mogelijk maakt om zeer veel van deze proteïnen en hun reacties gelijktijdig te bestuderen. Hierdoor kunnen bij allerlei ziekten, waaronder MS, de 
complexe biologische processen in kaart gebracht worden. Zo kunnen de typische eiwitprofielen bij MS vastgesteld worden. Voor betrouwbare resultaten vereist dit wel buitengewoon zorgvuldige afname, opslag en bewerking van het bloed of hersenvocht.

Momenteel kent de proteomics techniek nog veel hobbels, maar in de toekomst moeten de uitkomsten van dit type onderzoek voorspellend inzicht geven in de beloopsvormen van MS, de mate van ziekteactiviteit, de prognose en de te verwachten behandeleffecten. En dat zal invloed hebben op de therapiekeuze.

Een andere stap op weg naar beter maatwerk is de MRI-scan. Zoals eerder gezegd is de MRI voor het stellen van de diagnose MS van groot belang. Ook wordt MRI gebruikt om te meten wat het effect van therapie is. De relatie tussen aard, lokalisatie en hoeveelheid van de MRI-afwijkingen komt echter lang niet altijd overeen met de ziekte-verschijnselen en de ernst van de ziekte bij een patiënt. Bovendien weten we door belangrijk onderzoek van professor Barkhof en professor Polman aan de VU te Amsterdam dat de uitgebreidheid van de afwijkingen in de hersenen vaak veel groter is dan wordt waargenomen met de MRI. Daarom is MRI vooralsnog een surrogaatmiddel om de ziekteactiviteit in kaart te brengen en is verdere ontwikkeling van nieuwe MRI-technieken, zoals functionele MRI en de diffusion tensor imaging noodzakelijk om therapie-effectiviteit objectiever te kunnen monitoren.

Tenslotte zal verdere verfijning van de kennis van diverse immunologische processen in MS zowel met behulp van diermodellen als in mensgebonden onderzoek bijdragen tot meer maatwerk. Dit met name in relatie tot nieuw te ontwikkelen en te testen therapieën in de diverse stadia van MS. De neuro-immunologische inzichten bij MS zijn in voortdurende beweging: zo zijn er steeds meer bevindingen die duiden op beschermende auto-immunologische processen in plaats van een slechts schadelijke immunorespons en er is naast de T-celimmuniteit meer aandacht voor de rol van de B-celimmuniteit.

\section{Toekomstige ontwikkelingen.}

De afgelopen tien tot vijftien jaar is de kennis over oorzaak, diagnostiek en behandeling van MS sterk toegenomen, maar toch tasten we nog steeds in het duister omtrent de werkelijke causale mechanismen van de 
ziekte, en is de kennis van de pathofysiologie nog steeds te hypothetisch en te veel afgestemd op diermodellen en laboratoriumonderzoek. Bovendien is er nog steeds geen therapie die de oorzaak van MS bestrijdt. De kennis van genomen en proteomen in relatie tot de oorzaak van MS zal de komende tijd toenemen. Hierdoor zullen er nieuwe mogelijkheden voor een meer causaal gerichte therapie ontstaan.

Maar op korte termijn zijn er vooral veel ontwikkelingen op het gebied van de immunomodulerende therapie te verwachten. De behandeling met monoclonale antilichamen zal verder verfijnd worden en de omschakeling van louter intraveneuze of subcutane behandeling naar orale medicatie is een kwestie van tijd. Diverse orale middelen zijn in de eindfase van fase 3 -onderzoek en de resultaten hiervan zijn hoopgevend. Ook hebben we geleerd dat effectieve immunomodulatie of immunosuppressie bij MS in een vroege fase van de ziekte nodig is, om te voorkomen dat een cascade van ziektemechanismen tot onomkeerbare schade leidt.

Door de introductie van immunomodulerende medicijnen heeft de professionele belangstelling en daarmee de wetenschappelijke interesse in MS een enorme vlucht genomen.

Zoals eerder gesteld wordt een breed arsenaal aan medicijnen in fase 1-, 2- en 3-trials onderzocht. Dit zijn voornamelijk door de farmaceutische industrie gesponsorde en gedreven onderzoeken. Het is begrijpelijk dat sommige collega's hier kritiek op hebben, maar het is onterecht. Immers, gezien de extreem hoge kosten van dergelijk onderzoek en de beperkte huidige therapeutische mogelijkheden is deze manier van werken onvermijdelijk. Bovendien moeten de studies aan strakke internationale eisen voldoen en worden ze onafhankelijk gemonitord en kritisch beoordeeld door steering committees van de meest prominente MS-neurologen. Mijn zorg betreft eerder de praktijk van deelnemende centra: het objectiveren van de complexe en vaak zeer subjectieve eindpunten van dergelijk onderzoek is zeer moeilijk. Een systeem waarbij onafhankelijke MS-neurologen alle klinische data verifiëren zou hier soelaas kunnen bieden.

Op het terrein van basaal wetenschappelijk onderzoek zie ik zeker ook voordelen in samenwerking met de farmaceutische industrie. De lijnen tot het komen tot wetenschappelijke onderzoeksprojecten zijn kort en de contracten met industriële partners (vaak in de vorm unrestricted grants) zijn overduidelijk. In een tijd waarin het binnenhalen van projectsubsidies via de eerste geldstroom een vaak buitengewoon lange 
en omslachtige weg is en de enige grote MS-stichting in Nederland haar gelden nog steeds eenzijdig besteedt, is de samenwerking met de farmaceutische industrie dan ook zeer welkom, zolang de afspraken maar transparant zijn.

\section{Het regionaal academisch MS-centrum}

De vraag naar gespecialiseerde centra voor MS-zorg is sinds circa 2000 toegenomen, mede doordat er dure en soms complexe therapieën beschikbaar zijn gekomen en de inzichten omtrent de vaak multidisciplinaire behandeling van de MS-patiënt zijn veranderd. Deze behandeling is complexer en tijdsintensiever geworden. Verder is de MS-patiënt niet langer een afhankelijke patiënt aan wie de behandelaar weinig kan bieden. Vele patiënten zijn inhoudsdeskundigen geworden, die door internet kennis hebben van meerdere behandelfacetten. Steeds vaker zal de MS-patiënt dus zelf een specialist kiezen, vaak in gespecialiseerde MS-centra. Dit wordt ook gestimuleerd door de marktwerking.

Tot voor 1998 was er in Zuid-Nederland weinig academische belangstelling voor MS. Maar sinds die tijd kreeg de MS-zorg en research binnen de afdeling Neurologie van het azM extra aandacht hetgeen resulteerde in de oprichting van het Maastrichts MS-kennis-en- behandelcentrum

\section{Regionaal Academisch MS Centrum}

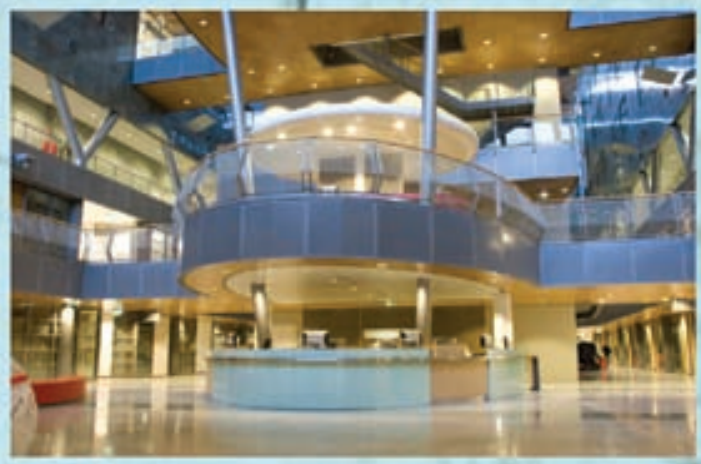


in 2000. De groei van het centrum werd echter beperkt door een aantal externe factoren. Er werd daarom samenwerking met de regio gezocht. Deze werd gevonden in Sittard bij collega Bert Anten die reeds een grote groep MS-patiënten in behandeling had.

De toenmalige decaan van de FHML, professor Harrie Hillen, lanceerde uiteindelijk het perfecte idee om in de regio één academisch MS-centrum op te richten dat gekoppeld zou zijn aan een leerstoel MS: de huidige formule. De afdelingen Neurologie van het MUMC en het Orbis Medisch Centrum zijn gaan samenwerken om dit te bereiken. Het huidige MS-centrum bevindt zich in Sittard, levert zorg aan ruim negenhonderd MS-patiënten en stelt zich ten doel supraregionale multidisciplinaire patiëntenzorg te verlenen op academisch niveau. Het MS-centrum moet een verwijscentrum zijn waar MS-patiënten uit Zuid-Nederland terecht kunnen voor een second opinion en, als zij dat willen, integrale multidisciplinaire zorg. Bovendien moet het centrum een prominente rol gaan vervullen bij het opstellen van diagnostische en therapeutische protocollen en richtlijnen.

\section{Wat zijn nu de voordelen van dit regionaal Academisch MS-centrum?}

Allereerst biedt het bij elkaar voegen van twee gespecialiseerde MS-poli's een verdubbeling van het aantal patiënten. Hiertoe zijn overigens prima lopende afspraken gemaakt tussen de afdelingen Neurologie van het MUMC en het Orbis Medisch Centrum. Alle nieuw gediagnosticeerde MS-patiënten in het MUMC worden voor verdere behandeling doorverwezen naar het regionaal academisch MS-centrum te Sittard. Bovendien blijkt het MS-centrum door zijn geografische ligging in combinatie met de academische uitstraling ook een grote aantrekkingskracht te hebben op MS-patiënten van buiten de regio. Van de huidige MS-patiënten die het centrum behandelt, komt meer dan $70 \%$ van buiten de regio Sittard.

Doordat het centrum veel patiënten bedient, is het mogelijk om met een vast behandelteam te werken, dat zorgt voor continuïteit en een constante bereikbaarheid, en dat een patiëntgerichte deskundigheid heeft ontwikkeld. Tijdens het multidisciplinaire spreekuur bezoekt de patiënt zowel de neuroloog alsook de MS-vepleegkundige 


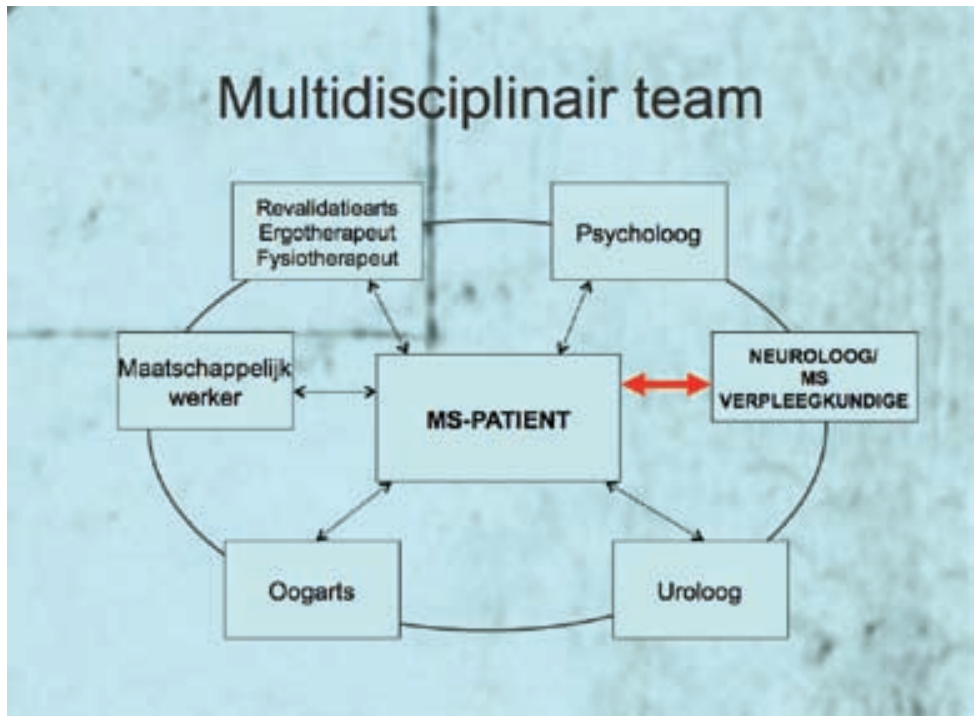

of nurse-practitioner. Zonodig worden revalidatie-arts, uroloog, oogarts, psycholoog of maatschappelijk werkende geraadpleegd. Ook worden de patiënten uitvoerig geïnformeerd over de nieuwste therapeutische ontwikkelingen en over de mogelijkheden tot deelname aan behandelingen in studievorm. Deze multidisciplinaire aanpak door een team van MS-deskundigen op uiteenlopende terreinen is zeer patiënt vriendelijk en effectief. Een echte meerwaarde voor de MS-patiëntenzorg.

Hoe moet het MS-centrum Sittard zich nu positioneren om binnen de eerder genoemde ontwikkelingen een belangrijke rol te spelen? Allereerst is het van eminent belang om de samenwerking tussen de academie het MUMC - en de perifere praktijk - het OMC - te intensiveren. Veel meer dan tot nog toe zouden de raden van bestuur van het MUMC en het OMC samenwerking op het gebied van onderzoek en patiëntenzorg moeten propageren en faciliteren. Aan de spelers in het veld zal het niet liggen: er zijn voldoende in de perifere praktijk werkende specialisten die goed gekwalificeerd zijn om wetenschappelijk onderzoek te verrichten en dit ook graag doen en omgekeerd zien academische specialisten veelal de voordelen van de samenwerking met de perifere praktijk: daar is immers een overvloed aan patiënten en patiëntengegevens die geschikt zijn voor wetenschappelijk onderzoek. 


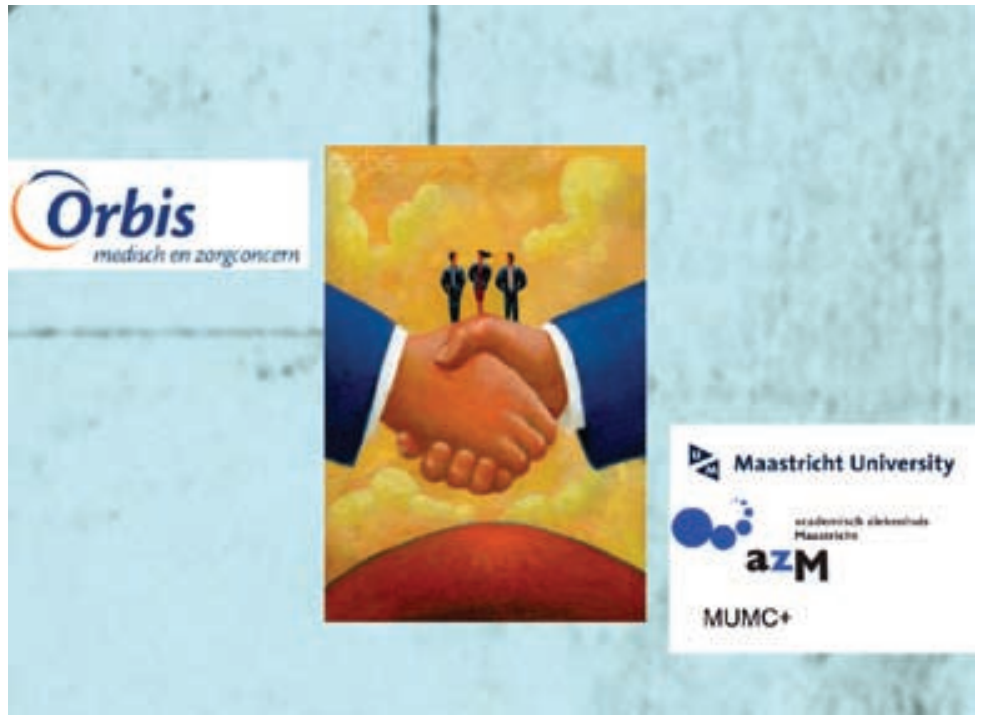

Naast onderzoek en patiëntenzorg zou deze samenwerking zich tevens moeten uitstrekken tot onderwijs en opleiding. Het regionaliseren van de opleiding tot neuroloog zou hier een belangrijke stap in kunnen zijn. Er is goede hoop dat de nieuwe opleider van de afdeling neurologie van het MUMC, collega Marc de Krom, en het nieuwe afdelingshoofd Neurologie van het MUMC deze ontwikkelingen met geweldige mogelijkheden verder zullen stimuleren.

Cruciaal is verder het optimaliseren van de patiëntenzorg. Dit betekent verdere concentratie van de MS-patiëntenzorg binnen het OMC. Versterking van de multidisciplinaire patiëntenzorg is daarvoor van belang. Interdisciplinaire lijnen moeten verbeterd worden, ook klinische behandeling en dagbehandeling moeten beter op elkaar afgestemd worden.

Verder dient de academische waarde van het centrum naar de collegae in de perifere praktijk beter gecommuniceerd te worden. Middelen hiertoe zijn onder meer de service bij het geven van second opinions, het periodiek beschikbaar stellen van onderzoeks- en behandelprotocollen en de communicatie via de website, bijvoorbeeld door middel van een nieuwsbrief.

Naast de al besproken intensieve samenwerking tussen de afdelingen Neurologie van het Orbis Medisch Centrum en het MUMC zou de positie 


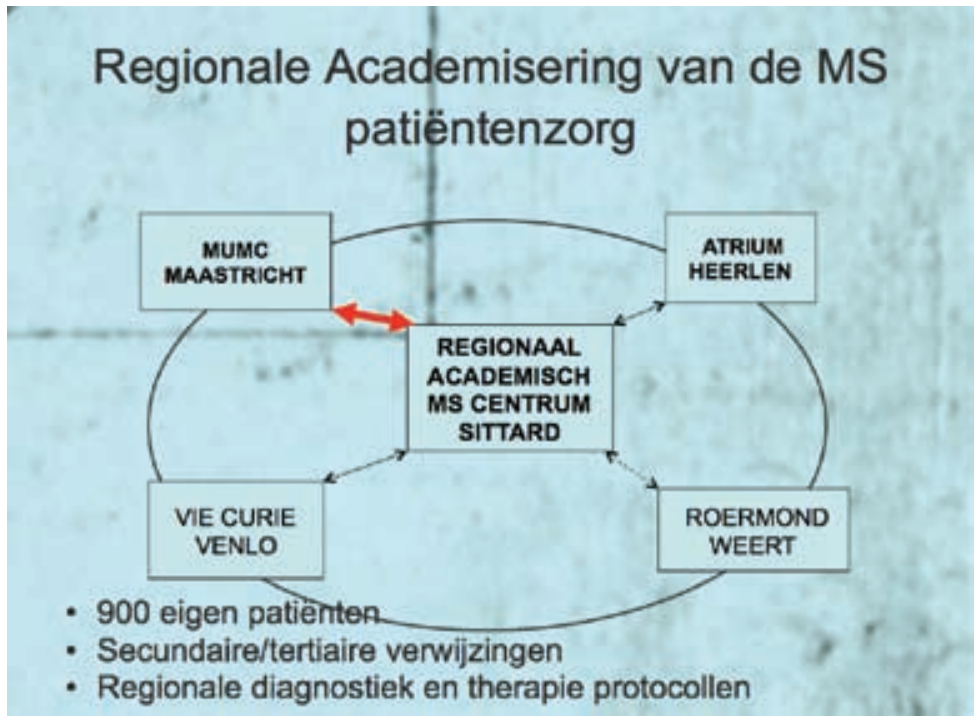

van het regionale MS-centrum en daarmee die van de MS-patiëntenzorg en de regionale MS-patiënt versterkt kunnen worden door de afdelingen Neurologie van het Atriumziekenhuis in Heerlen en die van het Vie Curie ziekenhuis in Venlo met de respectievelijke collega's Van Diepen en Pop te laten participeren in de patiëntenzorg van het MS-centrum.

Tenslotte moet naast patiëntenzorg en opleiding de meerwaarde van het MS-centrum uiteraard blijken uit de resultaten van eigen wetenschappelijk onderzoek.

\section{Wetenschappelijk onderzoek}

Ondanks meer dan een eeuw van onderzoek is MS nog steeds een mysterieuze ziekte. Verfijning van de diagnostiek, toename van de kennis van de oorzaak en pathofysiologie en vooral ook de ontwikkelingen op het terrein van de therapie hebben veel vooruitgang opgeleverd, maar hebben ook veel nieuwe vragen opgeroepen. De kennis omtrent de oorzaak van MS, die cruciaal is voor het ontwikkelen van een meer op de oorzaak gerichte therapie is eerder verbreed dan verdiept. Daarom is verder onderzoek naar oorzakelijk factoren van MS uiteraard van groot belang. De verfijning van het genetisch onderzoek zal hierbij een belangrijke rol spelen. Een rader in dit geheel vormt ons onderzoek naar 
de betekenis van diverse genetische afwijkingen, de polymorfismen van het vitamine D-receptorgen. Ook zijn er toenemende aanwijzingen dat er een omgekeerde relatie bestaat tussen de hoeveelheid zonlicht en de ernst van MS. Mogelijk is dat laatste vitamine D-afhankelijk. In dit kader verrichten wij momenteel een grote databasestudie onder meer dan tienduizend MS-patiënten waarbij gekeken wordt naar de invloed van de seizoensfluctuatie op de ernst van de verschijnselen in relatie tot de lengtegraad c.q. de hoeveelheid uv-licht.

Verder blijkt uit eigen onderzoek dat er een relatie is tussen de vitamine D-waarden en de klinische verschijnselen van MS. Deze bevindingen suggereren dat vitamine D een ziektemodulerend effect heeft bij MS. Verder suggereren recente, nog niet gepubliceerde, resultaten dat in MS patienten vitamine $D$ het afweersysteem in een minder inflammatoire, beter gereguleerde richting lijkt te sturen. Daarom wordt onderzocht, door middel van een trial, wat de effecten van hoge doses vitamine $D$ als toegevoegde behandeling zijn op het beloop van MS. Deze studie zal worden uitgevoerd in diverse grote centra binnen Nederland en waarschijnlijk ook daarbuiten. De bezielende kracht achter de vitamine D-projecten is promovendus Joost Smolders. In dit kader volgt ook een project, opgezet door Evelyn Peelen, waarbij de invloed van uv-straling op het vitamine D- metabolisme en op de immunologische respons bij MS patiënten wordt onderzocht.

Een door ons opgezette studie die op korte termijn gaat starten, is een studie naar de effecten op het beloop van MS van behandeling met het sterk afweeronderdrukkende medicijn mitoxantrone gevolgd door het immunomodulerende middel glatirameracetaat. Deze studie wordt uitgevoerd bij patiënten in een meer gevorderd stadium van de ziekte. Het project wordt gedragen door Stephanie Knippenberg.

Zoals reeds eerder geschetst zijn onderzoeken van de diverse immunologische gevolgreacties met name de T-cel of T-regulatoire-cel gebonden reacties en de onderzoeken van genetische mechanismen, te weten het onderzoek naar MS-polymorfismen, een soort van rode draad door de diverse projecten. Deze immunologische studies staan onder leiding van Jan-Willem Cohen Tervaart, Jan Damoiseaux en Mariëlle Thewissen.

Een meerjarenproject in wording gaat over de vroege opsporing van MS. Dit is een project waarbij ook huisartsen zullen worden betrokken. Verder organiseert het MS-centrum niet alleen eigen onderzoeken, 
maar neemt het ook deel aan diverse door de farmaceutische industrie geïnitieerde geneesmiddelen trials. Momenteel lopen er zeven fase 2- of 3-studies waarvan een drietal met orale medicatie.

Een volgend punt van wetenschappelijke interesse binnen ons centrum zijn de cognitieve stoornissen en moeheid bij MS. In dit kader loopt het nagenoeg voltooide promotietraject van Yvonne Bol over diverse neuropsychologische variabelen en moeheid in relatie tot MS. Gezien de hoge frequentie van progressieve cognitieve stoornissen bij MS is het zinvol deze te objectiveren en te vervolgen in de loop van de tijd. Derhalve wordt een plan uitgewerkt voor een longitudinale registratie van cognitieve stoornissen bij MS. De toegenomen technische mogelijkheden van functionele MRI binnen de FHML zullen daarbij zeker benut worden.

Zoals al eerder gesteld maken de complexiteit en heterogeniteit van de ziekte MS dat er een sterke behoefte is aan objectieve meetmethoden voor diagnosestelling, prognosestelling, duiding van het ziektetype en evaluatie van het behandeleffect. Deze objectieve parameters zouden gevonden kunnen worden in de zogenoemde biomarkers. In dit kader heeft de onderzoeksgroep van de universiteit van Hasselt/Diepenbeek een eigen techniek ontwikkeld: de serologische antigeenselectie (SAS).

\section{Wetenschappelijke samenwerking}

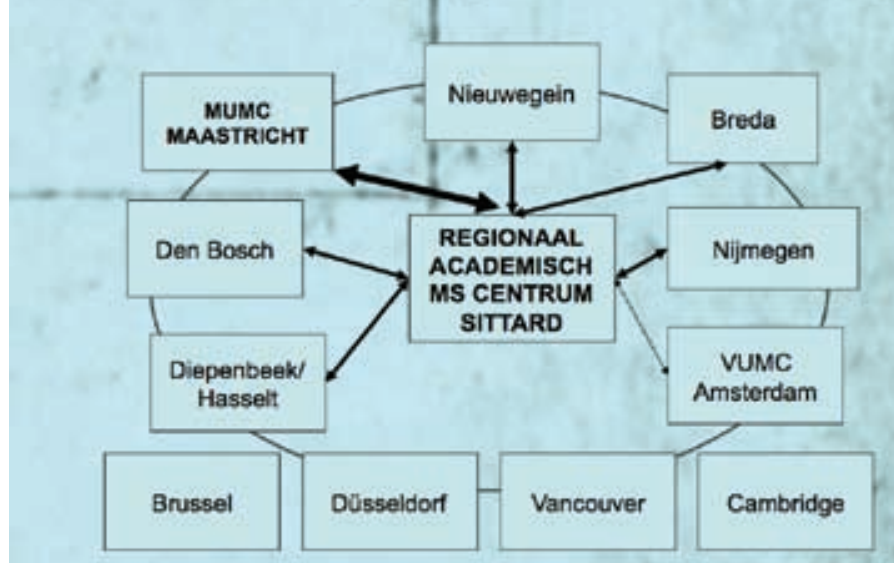


De onderzoeksresultaten tot nu toe wijzen op diverse MS-specifieke biomarkers die mogelijk van diagnostische waarde zijn. Bij dit onderzoek zijn we nauw betrokken.

Ook is er proteomics onderzoek bij MS-patiënten opgestart in samenwerking met de afdelingen Klinische chemie van het MUMC en die van het Orbis Medisch Centrum.

Diverse van de hiervoor genoemde onderzoeksprojecten vinden plaats in samenwerking met de grote MS-centra van Breda, Nijmegen, Den Bosch en Nieuwegein en er is ook een begin gemaakt met samenwerking met het internationaal gerenommeerde MS-centrum van de VU in Amsterdam onder leiding van professor Chris Polman.

Intensivering van deze samenwerkingsverbanden heeft prioriteit. Ten slotte zijn er belangrijke internationale contacten. De samenwerking met de MS-onderzoeksgroep van de universiteit van Diepenbeek/Hasselt onder leiding van Piet Stinissen en Veerle Somers is al intensief. Op termijn is samenwerking met de universiteitscentra van Brussel en Düsseldorf zeker mogelijk en eventueel ook met die van Aken en Luik. De banden met vancouver en Cambrigde zullen opnieuw aangehaald worden.

Samenvattend kan ik stellen dat de kennis van en de belangstelling voor MS het afgelopen decennium explosief gestegen is. Dit heeft geleid tot

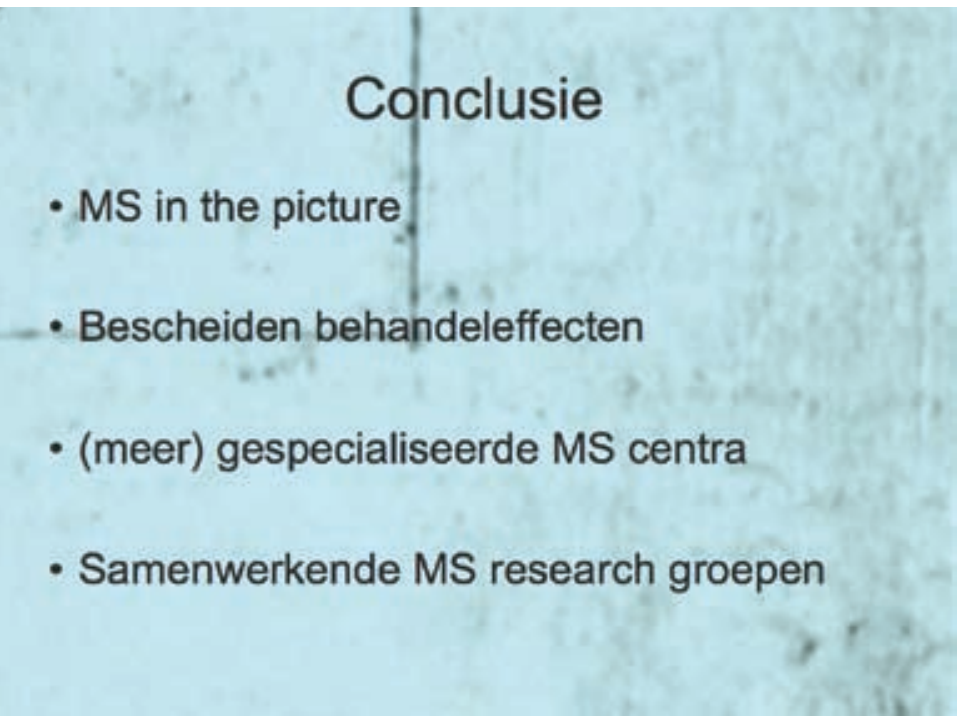


een aantal behandelingsopties met vooralsnog bescheiden effecten. In de naaste toekomst verwacht ik voor de behandeling van MS verdere concentratie van MS- patiëntenzorg in daartoe gespecialiseerde centra in samenwerking met omliggende ziekenhuizen. Deze samenwerking is ook van groot belang voor de wetenschappelijke voortgang op het terrein van MS. 


\section{Besluit}

Dames en heren,

Deze leerstoel heeft een ietwat ongewone voorgeschiedenis die ik kort wil schetsen.

Midden jaren negentig vertrok de toenmalige MS-neuroloog Wim Weber naar de pijnpoli van het azM. Ik maakte toen de overstap van vasculair neuroloog naar MS-neuroloog en daartoe aangespoord door het toenmalig hoofd van de afdeling Neurologie Jaap Troost verbleef ik vervolgens een half jaar in Vancouver Canada, waar ik van Joël Oger en Don Paty leerde hoe je een MS-kliniek moet runnen. Daarna had ik het genoegen ruim een half jaar mee te draaien in het gerenommeerde researchteam van Alastair Compston in Cambridge, Engeland. Zeer gemotiveerd tot het opzetten van een academisch MS-centrum in het azM kwam ik vervolgens terug uit het buitenland. En hoewel er al snel mede dankzij de facilitatie van het management van het azM een goedlopend MS-team functioneerde, ging het vervolg niet vanzelf. In plaats van MS-onderzoek te gaan doen werd ik voor anderhalf jaar interim hoofd van de afdeling Neurologie. Nadien was MS geen speerpunt meer van de afdeling Neurologie, hetgeen verdere uitbouw van de MS-kliniek en het MS-onderzoek blokkeerde.

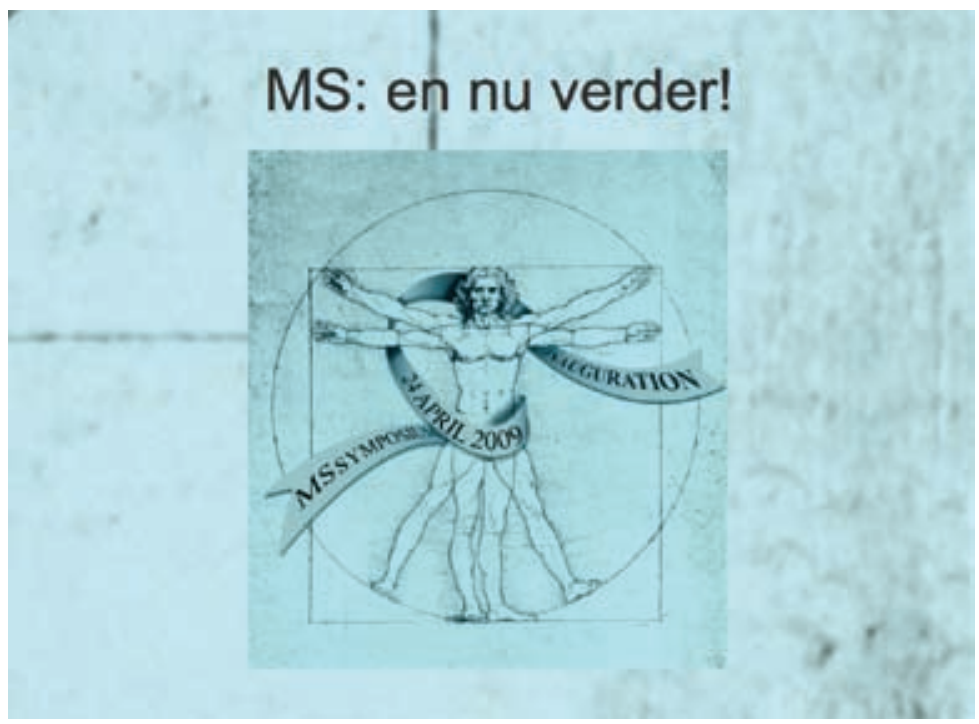


Hoewel op dat moment de multidisciplinaire MS-patiëntenzorg inmiddels uitstekend liep, trad er toch bezwaarlijke stagnatie op, die een volwaardige academische MS-afdeling onmogelijk maakte. De raad van bestuur beoordeelde een nieuw businessplan MS weliswaar positief op inhoud, maar vanwege de kleinschaligheid kon het plan toch geen doorgang vinden. Inmiddels waren er wel ondubbelzinnige afspraken met de decaan van de FHML en de voorzitter van de raad van bestuur van het MUMC over een gefaseerde uitbouw van het MS-centrum en over facilitering van de MS-research. Toen dan tenslotte de decaan van de FHML kwam met het voorstel van een perifeer gelokaliseerd MS-centrum voor de regio en daaraan gekoppeld een MS-leerstoel, bleek dit de gouden zet. De aard van de leerstoel is verder bijzonder in de zin dat het een samenwerkingsverband betreft tussen drie partijen, te weten: de FHML, het MUMC en het Orbis Medisch Centrum. Wellicht door dit ongewone karakter van de leerstoel heeft de instelling ervan de decaan uiteindelijk nog behoorlijk wat zweetdruppels gekost. 


\section{Dankwoord}

Ik kom dan nu tot mijn dankwoord. Het moge duidelijk zijn dat deze leerstoel er niet zou zijn gekomen zonder de blijvende steun en het vertrouwen van een aantal mensen om mij heen.

Allereerst dank ik het voormalig hoofd van de afdeling Neurologie Jaap Troost. Hij heeft de ontwikkeling van het MS-centrum in woord en daad gestimuleerd. Niet alleen maakte hij samen met de staf Neurologie mijn verblijf in het buitenland mogelijk, maar bovendien wisten we samen de nodige budgetten bij het management los te weken ter facilitatie van het MS-centrum.

Met de blijvende contacten met mijn grote voorbeelden de MS-autoriteiten Joël Oger en Alastair Compston ben ik zeer verheugd. Dear Joël, I'm really greatfull that you have given me the opportunity to learn how to run a MS-clinic. I thank you for your hospitality and friendship. And I'm really happy to have you here today. Dear Alastair, although I failed during my fellowship in Cambridge at the moment supreme playing the tennis match between Oxford and Cambridge, our contacts are still very positive. I'm proud to have you as an absolute authority in MS-research here today at my inauguration and at the preceeding MS-symposium. I hope that we can intensify our contacts and collaboration in the next future.

Furthermore I want to thank the other contributors to the MS-symposium, Frauke Zipp, Veerle Somers, Bert t Hart, Ludwig Kappos, Otto Hommes and Chris Polman. You have made this day one of an excellent scientific standard and I feel very honoured with you here today. I hope to keep in contact over the next time.

In het bijzonder wil ik me ook richten tot de bestuurders.

Ik realiseer me dat het instellen van een extern gepositioneerde leerstoel MS de afgelopen jaren zowel voor de FHML en het MUMC alsook voor het Orbis Medisch Centrum geen topprioriteit had. Sterker nog, ik schat het in als een moeilijk item dat politiek niet erg handig ligt. Dat het er toch van is gekomen dank ik aan de oprechtheid en vastberadenheid van allereerst de voormalige decaan van de FHML Harry Hillen, verder de directie van het MUMC en dan met name Guy Peeters en Lou BransBrabant en de toenmalige voorzitter van het Orbis Medisch Centrum Ludo Janssen. Ik dank jullie zeer voor het vertrouwen, de blijvende steun en de vele inspanningen die jullie voor mij geleverd hebben. 
De maatschap Neurologie te Sittard. Bert Anten ben ik zeer veel dank verschuldigd. In feite is hij de man die mij naar Sittard gehaald heeft. Jammer dat vanwege zijn pensioen onze samenwerking nu minder intensief is. De huidige maatschap Neurologie Veronique Triebels, Fergus Rooyer, Humphrey Morré, Peter van Domburg, Hans ter Berg, Nathalia Bouwman en tot voor kort Piet Wuisman, ben ik eveneens zeer veel dank verschuldigd. Ook het mij toestaan van een status aparte binnen de groep met onder meer extra researchtijd waardeer ik hogelijk. Mede door de sterke betrokkenheid van het secretariaat waarvan ik met name wil noemen Ans Hennen en Jolanda Aussems, was het na 25 jaar azM bij jullie toch een beetje thuiskomen.

Ik dit kader wil ik ook graag de directie van het voormalige Maaslandziekenhuis Cees Sterk, Ria Bosschaert en Roel Goffin danken voor hun vertrouwen en steun.

De motor van het MS-team vormen de MS-verpleegkundigen, de research-verpleegkundige en de nurse-practitioner Tiny Kempkens, Bertine Timmermans, Judith Poeth, Sandra Liedekerken en Ingrid Mevissen. Samen met de maatschappelijk werkende John Wijntjens zijn zij door middel van hun buitengewone gedrevenheid en betrokkenheid het kloppend hart van het MS-centrum. Zeer veel dank en erkentelijkheid hiervoor.

De aanstaande MS-promovendi van het eerste uur zijn Yvonne Bol, Joost Smolders, Stephanie Knippenberg en Evelyn Peelen. Ik dank jullie voor jullie sprong in het diepe en voor jullie uitstekende MS-research. Veel dank ben ik verschuldigd aan de immunologen Jan-Willem Cohen Tervaart, Jan Damoiseaux en Mariëlle Thewissen voor hun geloof in MSonderzoek vanaf het prille begin en voor de succesvolle samenwerking. De tijd van oogsten is eindelijk daar.

Ik dank de vrijwilligsters van het MS-inloopcentrum te weten Ria Roos, Rinie Pustjens, Annie Bruls, Louise Schalkwijk, Monique Baeten, Sonja Nieddu, Marian Lijesen en Manieta Karman voor al hun geïnvesteerde tijd en energie.

Niet in de laatste plaats dank ik de MS-patiënten voor hun vertrouwen en voor een niet aflatende bereidheid tot deelname aan wetenschappelijk onderzoek.

Mijn vrienden dank ik voor hun trouw, een van hen in het bijzonder, Erik, voor meer dan 40 jaar vriendschap in voor- en tegenspoed. 
Graag dank ik ook mijn familie. Ik ben zeer verheugd dat mijn ouders hier vandaag bij kunnen zijn. Speciaal dank ik hen en mijn schoonouders. Ze waren en zijn er altijd.

Tenslotte Lianne, voor je liefde en steun en voor onze drie prachtige kinderen, Michel, Céline en Dominique.

Ik heb gezegd. 


\section{Referenties}

1. Kobelt G. et al.

Cost and quality of life in multiple sclerosis in The Netherlands.

Eur J. Health Econ. (2006) 7:S55-S64.

2. Polman C.H., Reingold S.C., Edan G. et al.

Diagnostic criteria for multiple sclerosis: 2005 revisions to the 'McDonald Criteria'.

Annals of neurology 2005; 58:840-846.

3. Fisniku L.K., Brex P., Altman D. et al.

Disability and T2 MRI-lesions: a 20 -year follow up of patients with relapse onset of multiple sclerosis.

Brain 2008; 131:808-817.

4. Langer-Gould A., Popat R.A., Huang S.M. et al.

Clinical and demographic predictors of long-term disability in patients with relapsing-remitting mutiple sclerosis.

Archives of neurology 2006; G6:1686-1691.

5. PRISMS Study Group, PRISMS-4: long-term efficacy of interferon-beta-1a in relapsing MS.

Neurology 2001; 56:1628-1636.

6. The CHAMPS Study Group. Intramuscular interferon-beta-1a therapy initiated during a first demyelinating event in multiple sclerosis.

N Engl J Med 2000; 343:898-904.

7. Comi G. Filippi M., Barkhof F. et al.

Effect of early interferon treatment on conversion to definite multiple sclerosis: A randomised study.

Lancet 2001; 357: 1576-1582.

8. Kappos L. Freedman MS, Polman C.H. et al, for the BENEFIT Study Group. Effect of early versus delayed interferon-beta- $1 b$ treatment on disability after a first clinical event suggestive of multiple sclerosis: a 3-year follow-up analysis of the BENEFIT study.

Lancet 2007; 370:389-397.

9. Comi G., Filippi M., on behalf of the PreCISe Study Group.

Treatment with glatiramer acetate delays conversion to clinically definite multiple sclerosis in patients with clinically isolated syndromes suggestive of multiple sclerosis.

J. Neurology 2008; 255 (suppl 2):10. 
